\title{
Feed Intake, Blood Parameters, Digestibility and Live Weight Gain of Male Bali Cattle (Bos javanicus) Fed Ammoniation Rice Straw Supplemented by Waru (Hibiscus tiliaceus) Flower Extracts
}

\author{
Sri Rahayu*, Veven Raymexen Bonat and Muhamad Bata \\ Faculty of Animal Science, Jenderal Soedirman University, Purwokerto, Indonesia \\ *Corresponding author email: sirahayu27@gmail.com
}

\begin{abstract}
The objective of this study was to evaluate the effect of Hibiscus tiliaceus flower extracts supplementation in concentrate on performance, nutrient digestibility and blood metabolites of Bali cattle. Sixty of male Bali cattle averaging $225 \pm 09.15 \mathrm{~kg}$ initial body weight were used in this study. They were divided into two groups. The first group (as control) was cattle fed ammoniated rice straw and concentrate (R1) and the second group was fed as the same as the control group, but concentrate was supplemented with $H$. tiliaceus flower extract at $200 \mathrm{ppm} / \mathrm{kg}$ of dry matter (R2). Variables measured were dry matter digestibility (DMD), organic matter digestibility (OMD), neutral detergent fiber digestibility (NDFD), and acid detergent fiber (ADFD) using total collection method. Other variables were blood glucose and urea, average daily gain (ADG), feed conversion (FC) dan feed efficiency (FE). T-test showed that DMD, OMD, ADFD, and NDFD in the second group (R2) were higher $(P<0.05)$ than control $(R 1)$. However, there was no significant difference $(P>0.05)$ between performance (ADG, FC, FE) and blood parameters of urea and glucose between the groups fed diets supplemented with $\mathrm{H}$. tiliaceus flower extracts and control group. There was an increase in ADG and FE on R2 $(0.63 \pm 0.23 \mathrm{~kg}$ and FE $5.54 \pm 1.89)$ compared to R1 $(0.54 \pm 0.32 \mathrm{~kg}$ and $0.54 \pm 0.32)$. The study concluded that supplementation of Hibiscus tiliaceus flower extracts as feed additive in the concentrate diet can increase nutrient digestibility and tend to improve the performance of Bali cattle.
\end{abstract}

Keywords: digestibility, saponins, Hibiscus tiliaceus, performance, Bali cattle

\begin{abstract}
Abstrak. Penelitian bertujuan mengkaji pengaruh suplementasi ekstrak bunga Waru (Hisbiscus tiliaceus) dalam konsentrat terhadap performa, kecernaan pakan dan metabolit darah sapi Bali. Sejumlah 60 ekor sapi Bali jantan dengan rerata bobot badan sekitar $225 \pm 09.15 \mathrm{~kg}$ dikelompokan menjadi dua grup, grup pertama (kontrol) sapi yang diberi pakan basal berupa jerami padi amoniasi dan konsentrat dengan rasio 40:60\% (R1) sedangkan grup ke dua (R2) adalah kelompok sapi yang diberi pakan basal namun pakan konsentrat disuplementasi dengan 200 ppm (per kg bahan kering) ekstrak bunga Waru. Peubah yang diamati dan diukur adalah kecernaan bahan kering, bahan organik, NDF (neutral detergent fiber) dan ADF (acids detergent fiber) menggunakan metode koleksi total. Peubah yang lain adalah glukosa dan urea darah, pertambahan bobot badan harian (PBBH), efisiensi dan konversi pakan. Uji T menginformasikan bahwa kecernaan bahan kering, bahan organik, NDF dan ADF pada grup R2 nyata lebih tinggi $(\mathrm{P}<0.05)$ dibandingkan kontrol $(\mathrm{R} 1)$. Namun demikian tidak ditemukan perbedaan nyata $(\mathrm{P}>0.05)$ antara performa $(\mathrm{PBBH}$, efisiensi dan konversi pakan) serta parameter darah (urea dan glukosa darah) diantara kedua grup. Meski secara statistic suplementasi ekstrak bunga Waru tidak nyata, namun terdapat kecenderungan peningkatan PBBH dan efisiensi pakan pada R2 (0.63 $\pm 0.23 \mathrm{~kg}$ dan FE $5.54 \pm 1.89)$ vs $\mathrm{R} 1(0.54 \pm 0.32 \mathrm{~kg}$ dan $0.54 \pm 0.32$ ). Supplementasi ekstrak bunga Waru (H. tiliaceus) sebagai aditif pakan dalam konsentrat sapi Bali mampu meningkatkan kecernaan nutrient pakan dan cenderung memperbaiki performa sapi Bali.
\end{abstract}

Kata kunci: kecernaan, saponin, waru, performa, Sapi-Bali

\section{Introduction}

Bali cattle are native Indonesian cattle that have distinctive characteristics and high economic value. The total population of Bali cattle in 2014 was 49,658, and it increased to 52,811 in 2015 (Biro Pusat Statistik, 2016). Bali cattle is one of the Indonesian national assets that have the potential to be improved because it has a high fertility rate of $83-86 \%$ and desirable adaptability to extreme environments (Wiswata et al., 2016). These benefits make Bali cattle considered the prime cattle in Indonesia (Gunawan et al., 2011). However, Bali cattle have a disadvantage of a slow rate of body 
weight gain, its $0.3 \mathrm{~kg} /$ day approximately (Ngadiyono, 2012).

Researchers need to put concerted effort to increase the productivity of Bali cattle through improving feed quality to manipulate rumen conditions using saponin as an additive. Several studies reported the use of plant substances as natural additives for rumen manipulation (Kim et al., 2012; Yildiz et al., 2015). Natural additives such as fumaric acid and malate acid in plant extracts used as methane inhibitors, it was demonstrated in vitro (Baraka and AbdlRahman, 2012; Jayanegara et al., 2012) and in vivo (Geraci et al., 2012; Jayanegara et al., 2012; Cruz et al., 2014). Organic acids from plant extracts are used as precursors to propionate formation via the succinate-propionate pathway and propionate formation as an alternative to $\mathrm{H} 2$ sinks. This process potentially reduces the methane production in rumen (Belanche et al., 2014). Plant saponin extracts supplemented in dairy cattle ration were reported to inhibit the population of protozoa cilliata (Faniyi et al., 2016; Wang et al., 2012). Defaunation agents (protozoa inhibitors) have the ability to suppress methane gas (Faniyi et al, 2016) because $25 \%$ of methanogenic bacteria have a symbiotic mutualism relationship with protozoa (Kim et al., 2012).

Hibiscus tiliaceus is a tropical plant traditionally used to treat cough, gastroenteritis, skin disease, and diarrhea. Bioactive agents in Waru leaves are amides, vanillic acid, scotoletin, saponins and fumaric acid (Kumar et al., 2008); whereas in Waru flowers, there are phenols, flavonoids and saponins, and their concentrations are higher in flower than leaves (Bata and Rahayu, 2017). The positive effect of plant extracts flavonoids on methane emissions and methanogenic populations both in vitro and in vivo has been studied (Oskoueian et al., 2013; Bodas et al., 2012; Becker et al., 2014; Kim et al., 2015). Balcells et al. (2012) reported that flavonoid supplementation improved rumen fermentation of dairy cows, increased milk production, prevented ruminal acidosis through reduction of Streptococcus bovis and Selenomonas ruminantium and also increased the number of lactate user bacteria such as Megasphaera elsdenii, which ultimately led to improved performance of the beef cattle.

Flower extracts of $\mathrm{H}$. tiliaceus contain saponin and fumaric acid at $10.5 \%$ and $8.4 \mathrm{ppm}$ (Bata and Rahayu, 2017). Saponins increased rumen microbial protein synthesis and reduced the rumen cilliata protozoa (Kumar et al., 2017; Wang et al., 2012). Whereas fumaric acids and vanillic acids as precursors of propionate synthesis suppressed methane gas production by use of hydrogen gas for propionate synthesis (Benchaar et al., 2007). Propionic acid is a glucogenic compound that plays a vital role in fat metabolism and fat deposition in beef cattle. Based on the description above, Waru flower extracts have a high potential to increase cattle productivity. However, information on Waru flower extracts as a feed additive for fattening Bali cattle has not been studied.

\section{Materials and Methods}

\section{Materials}

A total of sixty male Bali cattle aged 2.5 - 3.5 years, averaging $225 \pm 09.15 \mathrm{~kg}$ initial body weight, were used in this study. The cattle were imported from Timor Island and were given worm drugs at the beginning of this experiment. The animals were housed in individual stalls of 2 $\mathrm{m}$ length, $0.75 \mathrm{~m}$ width and $2.5 \mathrm{~m}$ heights. The stall had separate feed and drinking troughs.

Ammoniation of rice straw used urea of $5 \%$ and added $2,5 \%$ of cassava byproducts as additive to reduce ammonia that resulted from ammoniation processing. The concentrate was composed of $47.6 \%$ waste cassava, $24.0 \%$ pollard, $10 \%$ rice bran, $5.7 \%$ coconut meal, $7.0 \%$ soybean meal, $10.5 \%$ palm kernel meal, $0.6 \%$ urea, $1.6 \%$ dolomite, $0.3 \%$ mineral, $1.0 \%$ salt and $4.0 \%$ molasses. The nutrient content of ammoniated rice straw, concentrates, and ration is shown in Table 1. 
Waru flowers $(H$. tiliaceus) were obtained from the coastal area of Cilacap-Central Java. They were dried in the oven of $50^{\circ} \mathrm{C}$ for two days and ground into powder. Waru flowers powder was extracted in ethanol according to Bata and Rahayu (2016) as follows: One hundred grams of Waru flower powder was dissolved in $1 \mathrm{~L}$ of $70 \%$ ethanol at room temperature for 24 hours. The filtrate was evaporated at $70^{\circ} \mathrm{C}$ until volume retained $\pm 10 \mathrm{ml}$ approximately, then it was added $10 \mathrm{~g}$ of tofu byproduct powder. The mixture was dried at $50^{\circ} \mathrm{C}$ in the oven for two days and ground in a laboratory mill to obtain extracted powder.

\section{Feeding and Management}

The animals were divided into two groups, randomly. The first group $(n=30)$ as control was cattle fed ammoniated rice straw and concentrate (R1), and the second group received diets as the same as the control group, but concentrate was supplemented with Waru $(H$. tiliaceus) flower extract at $200 \mathrm{ppm} / \mathrm{kg}$ of dry matter (R2). The number of concentrates were fed at $2 \%$ of body weight, while ammonia rice straw was prepared adlibitum. Concentrates were offered to the animals two times a day at 07.00 and 14.00 .

Feeding trial was conducted for 3 months and started by a preliminary period for 14 days. At the end of the preliminary period, all of cattle were weighed to obtain early body weight and repeated each month for three months. Digestion trial was carried out after the feeding trial using the total collection method. During the collection, the animals were fitted with harnesses to ensure the separation of urine and feces.

Feces, feeding and leftover feed were weighed and recorded daily for 5 days. During feces collection, every 4 hours was sprayed with $10 \%$ formalin. Repsentatif sample of feces, feed offered and refused were collected of 2, 2 and $5 \%$ of the total, respectively. The samples were dried in the oven at $60^{\circ} \mathrm{C}$ for three days. Ammoniation rice straw was cor-sampled and concentrates and feces were grab-sampled and composed for each treatment for analysis of chemical composition.

Blood sample collection for glucose and urea blood analysis were conducted at the end of the digestion trial. The blood samples were taken two hours after cattle were fed concentrate through the jugular vein using venoject with anticoagulant. After centrifuging at $2000 \mathrm{~g}$ for 5 minutes, all samples were stored in the freezer in aliquots awaiting analysis for glucose and urea analysis.

\section{Chemical Analysis}

Ammoniation rice straw, concentrate and feces samples were ground to pass a $1 \mathrm{~mm}$ screen to determine dry matter, organic matter, NDF, and ADF (AOAC, 2012). Blood urea measurements using urease (Chaney and Marbach, 1962) and blood glucose using Trinder's reaction (Barham and Trinder, 1972). Measurement of plasma glucose refered to as enzymatic method was applied using colorimetric techniques according to the manufacturer's instructions.

Table 1. Nutrient Composition of concentrate, ammoniated rice straw and ration

\begin{tabular}{lcccccccc}
\hline \multirow{2}{*}{ Feed } & DM & \multicolumn{9}{c}{$\%$ DM } & GE \\
\cline { 3 - 7 } & $(\%)$ & CP & CF & Ash & NFE & ADF & NDF & (MJ) \\
\hline Concentrate (60\%) & 83.39 & 15.13 & 26.63 & 72.6 & 56.01 & 26.31 & 55.69 & 3.3054 \\
Ammoniated Rice straw & 40.72 & 6.17 & 37.94 & 15.73 & 66.65 & 51.00 & 59.51 & 3.5964 \\
$\begin{array}{l}\text { (40\%) } \\
\text { Ration }\end{array}$ & 66.32 & 11.55 & 31.154 & 49.85 & 60.266 & 36.19 & 57.22 & 3.4218 \\
\hline
\end{tabular}

$\mathrm{DM}$, dry matter; $\mathrm{CP}$, crude protein; $\mathrm{EE}$, ether extract; $\mathrm{CF}$, crude fiber; NFE, nitrogen free extract;ADF, acids detergent fiber; NDF, nitrogen detergent fiber; GE, gross energy 
In this method, glucose was oxidized by glucose oxidase to gluconate and hydrogen peroxidase. Blood urea determination, urea in the serum samples was hydrolysed enzymatically into ammonium and carbon dioxide. The ammonium ions formed react with salicylate and hypochlorite in the presence of the catalyst nitroprusside to form a green indophenol.

\section{Statistics Analysis}

The collected data was analyzed using T Test analysis to determine the effect of treatment. The level of statistical significance was set at $P<0.05$. The study used statistical software package SPSS 15.0 (SPSS inc., Chicago, USA) for analysis.

\section{Results and Discussion}

\section{Nutrients Digetibility}

Supplementation of $\mathrm{H}$. tileaceus flower extract of $200 \mathrm{ppm} / \mathrm{kg}$ dry matter to concentrate diets of Bali cattle significantly affected on digestibility of dry matter, organic matter, NDF and ADF. The average digestibility coefficient of cattle group fed diet supplemented with $H$. tileaceus flower extract of (R2) was higher $(P<0.05)$ than cattle of control group fed diet without $H$. tileaceus flower extract. Adding of $H$. tileaceus flower extract caused increasing of $6.7 \%, 4.7 \%, 4.5 \%$ dan $6.9 \%$ for DMD, OMD, NDFD and ADFD, respectively (Table 2 ).

Digestibility coefficient of dry matter (DMD), organic matter (OMD), neutral detergent fiber (NDFD) and acid detergent fiber (ADFD)diets containing Hibiscus tileaceus flower extracts were significantly higher $(P<0.05)$ at $6.7 \%$ and
4.5\% compared to diets without adding of waru flower extract (Table 2). This was because $H$. tileaceus flower extract contains saponins which can suppress protozoa in the rumen. Bata and Rahayu (2016) reported that there was a tendency for the addition of $100 \mathrm{ppm} H$. tileaceus flower extract to reduce the population of protozoa, increase the total VFA product and the activity of rumen hydrolytic enzymes invitro. The reduction of protozoa resulted in an increase in the bacteria population, which digest nutrients in the diets. Some researchers reported that feed supplemented with saponins are capable of displaying a better digestibility profile because saponins have a defaunation effect that will suppress the protozoan population and alter microbial patterns in the rumen (Wang et al., 2012; Kumar et al., 2017; Aazami et al., 2013).

NDFD and ADFD diets containing $H$. tileaceus flower extract were significantly higher $(P<0.05)$ compared to the control cattle group. Guyader et al (2015) reported an increase in NDFD and ADFD in dairy cow fed tea saponin supplementation. Tea supplementation also enhances the apparent digestibility of OM, ADF and NDF in Ewe fed (Liu et al., 2019). These results are in contrast to the results obtained using saponin from yucca schidigera extract (Wang et al., 2009), which reportedly reduce crude fiber digestibility in vitro. The difference in the response of the effectiveness of saponins to the rumen microbial population is influenced by several factors, namely saponin structure, feed composition, microbiota adaptation, rumen biochemistry, saponin dose, microbial community in the rumen (Goel et al., 2012).

Table 2. Gross Eenergy (GE) Bali cattle fed ammoniated rice straw and concentrate supplemented by Waru flower extracts

\begin{tabular}{ccccc}
\hline Treatments & DMD (\%) & OMD (\%) & NDFD (\%) & ADFD (\%) \\
\hline$R_{1}$ & $69.02^{\mathrm{a}} \pm 5.67$ & $72.14^{\mathrm{a}} \pm 5.40$ & $68.63^{\mathrm{a}} \pm 5.57$ & $65,52^{\mathrm{a}} \pm 5.98$ \\
$\mathrm{R}_{2}$ & $75.69^{\mathrm{b}} \pm 3.47$ & $76.84^{\mathrm{b}} \pm 3.16$ & $73.17^{\mathrm{b}} \pm 3.82$ & $72.44^{\mathrm{b}} \pm 3.92$ \\
\hline
\end{tabular}

Means in the same column/row with different superscript differ significantly $(\mathrm{P}<0.05)$ or highly significant $(\mathrm{P}<0.01)$ 
Besides containing saponins, $H$. tileaceus flower extract also contains higher concentrations of flavonoids (Bata and Rahayu, 2017). Flavonoids have a role in maintaining the rumen ecosystem, especially in ruminants that fed high amounts of concentrate, as in this study. The effects of flavonoids on beef cattle were reported by (Balcells et al., 2012) that flavonoids prevent rumen acidosis by decreasing Streptococcus bovis and Selenomonas ruminantiumbacteria and increasing the number of lactate-using bacteria such as Megasphaera elsdenii to improve beef cattle performance. Kim et al., (2015) reported that supplementation of feed with various types of plants rich in flavonoids was able to maintain $\mathrm{pH}$ level. It seems that the presence of flavonoids in waru flower extract is one of the reasons for the increase in DMD, OMD, ADFD and NDFD of Bali cattle fed diets supplemented with $H$. tileaceusflower extract.

\section{Blood Glucose and Urea Levels}

Blood glucose and urea levels of Bali cattle were not significantly affected $(P>0.05)$ by adding of $H$. tileaceus flower extract in the diets. There was no significant difference $(P>0.05)$ between the control (R1) group and the treatment (R2). The blood glucose level of the treated cattle group tended to increase by $4.1 \%$ higher than the control (Table 3).

In the present study, there was no significant effect of $H$. tileaceus flower extract supplementation on glucose and urea blood; seemingly, the blood parameters were within the normal ranges (Kumar et al., 2017). Similar to our findings, a previous study reported that saponin containing diet did not affect blood parameters (Nasri et al., 2011), indicating that it is safe for feeding ruminants. This is presumably because the gross energy content (GE) between the treated feed and control feed is relatively the same (Table 2). According to McDonald et al., (2010) feed factors, especially energy consumption, greatly determine the high and low blood glucose levels. Church (1993) added that blood glucose levels are influenced by feed carbohydrates, both crude fiber and BETN. Crude fiber and BETN are fermented by rumen microbes to produce volatile fatty acids (VFA) such as acetate, propionate and butyrate. Propionate is converted to glucose in the liver (Wanapat et al., 2013). Propionic acid supplies $30 \%$ of the body's glucose needs (McDonald et al., 2010).

There was a tendency of an increase in blood glucose in treated cattle compared to control cattle. This was because saponins can reduce protozoa and indirectly have an impact on the reduction of methanogenic bacteria because approximately 25 to $30 \%$ of methanogenic is symbiotic with protozoa (Wang et al., 2012); thus, the process of methane production is hampered. Thus $\mathrm{H}_{2}$, as one of the elements of methane formation, is diverted to propionate formation, which results in increased production of propionate (Belanche et al., 2014). Greening et al. (2019) found that the increase in propionate was caused by competition for hydrogen between propionate and methane and the low acetate and butyrate, which are the main fermentation products of protozoa. Defaunation will change the VFA pattern, which results in high propionate production.

Table 3. Glucose and urea blood levels on Bali cattle fed ammoniated rice straw and concentrate supplemented by Waru flower extracts

\begin{tabular}{ccc}
\hline Treatments & Glucose $(\mathrm{mg} / \mathrm{dl})$ & Urea $(\mathrm{mg} / \mathrm{dl})$ \\
\hline$R_{1}$ & $33,40 \pm 14.23$ & $24,40 \pm 4.42$ \\
$R_{2}$ & $37.50 \pm 14.14$ & $24.00 \pm 5.52$ \\
\hline
\end{tabular}

Means in the same column/row with different superscript differ significantly $(P<0.05)$ or highly significant $(P<0.01)$ 
Propionate is the main ingredient for glucose formation through the process of gluconeogenesis. Prayitno et al., (2014) reported that blood glucose levels were influenced by the administration of saponins which were able to reduce methane gas production and increase propionate production.

Increasing of propionate is also caused by the flavonoids contained in Hibiscus tiliaceus flower extract. Balcell et al. (2012) reported that the addition of flavonoids in cattle diets fed high concentrations could increase propionate and reduce acetate. In addition, flavonoids can prevent rumen acidosis by decreasing Streptococcus bovis and Selenomonas ruminantium and an increase in the number of lactate user bacteria such as Megasphaera elsdenii so as to improve the performance of beef cattle.Kim et al., (2015) reported that supplementation of feed with various types of plants rich in flavonoids was able to maintain $\mathrm{pH}$. An increase in the population of lactate-user bacteria such as Megasphaera elsdenii will increase propionate because these bacteria can convert lactate to propionate, which is the main compound for glucose formation through the gluconeogenesis process. Therefore, blood glucose in cattle fed diet containing $\mathrm{H}$. tileaceus flower extract is higher than the control. Excess glucose is used to accumulate body fat, so cattle in this group have ADGs that tend to be better.

Blood urea levels (Table 3 ) in cattle fed with H. tileaceus extract did not differ $(P>0.05)$ from the control cattle group. This caused the protein content of the diet fed in the two groups of cows to be relatively the same, and the addition of 200 ppm of $H$. tileaceus flower extract does not cause an increase in the treated feed protein. Nozad et al. (2012) reported that there is a positive relationship between blood urea and feed proteins consumed by the ruminants. Ruminants fed additional protein in their diet reported high blood urea concentrations (Hasan and Saeed, 2012).

There was a tendency to decrease blood urea levels in the group of cattle receiving diet supplemented with $H$. tileaceus flower extrct. The use of $H$. tileaceus flower extract as a defaunation agent reduced the number of rumen protozoa thereby increasing the number of rumen bacteria. Increasing the number of rumen bacteria will increase the utilization of rumen $\mathrm{N}-\mathrm{NH} 3$ so that $\mathrm{N}-\mathrm{NH} 3$ levels absorbed through the rumen wall decreases. The reduced absorption of NH3 from rumen will significantly reduce the conversion of $\mathrm{N}-\mathrm{NH} 3$ to urea in the liver, so that blood urea levels also decrease. This is in accordance with the statement of Hasan and Saeed (2012) that urea levels in the blood are influenced by ammonia levels in the rumen.

\section{Performance}

Supplementation of $200 \mathrm{ppm} / \mathrm{kg}$ dry matter H. tileaceus flower extract into Balinese cattle diet did not affect $(P>0.05)$ the final body weight, average daily gain ( $A D G$ ), feed efficiency (FE) and feed conversion (FC). There was a tendency improving of $A D G, F E$ and $F C$ of group cattle received diet containing $H$. tileaceus flower extract (Table 4).

Average daily gain (ADG), feed efficiency (FE) and feed convertion (FC) in the group of cows fed with $H$. tileaceus flower extract were not significantly different $(P>0.05)$ with the control cattle group (Table 4).

This is because the feed given to both groups of cows contains a high enough concentration ( $2 \%$ of the live weight or equivalent to $65 \%$ of the total consumption of dry matter). This condition causes the rumen $\mathrm{pH}$ to be acidic. The acidic rumen condition causes the defaunation effect of saponin to be less effective. 
Table 4. Finale body weight, avergae daily gain (ADG), feed convertion and feed effisiency Bali cattle fedammoniated rice straw and concentrate supplemented by Waru flower extracts

\begin{tabular}{ccccc}
\hline Treatments & $\begin{array}{c}\text { Body } \\
\text { weight }(\mathrm{kg})\end{array}$ & ADG $(\mathrm{kg})$ & $\begin{array}{c}\text { Feed } \\
\text { Conversion }\end{array}$ & $\begin{array}{c}\text { Feed } \\
\text { efficiency (\%) }\end{array}$ \\
\hline $\mathrm{R}_{1}$ & $288.60 \pm 15.48$ & $0.54 \pm 0.32$ & $18.05 \pm 2.17$ & $5.54 \pm 1.89$ \\
$\mathrm{R}_{2}$ & $290.60 \pm 22.40$ & $0.63 \pm 0.23$ & $14.76 \pm 3.37$ & $6.77 \pm 2.66$ \\
\hline
\end{tabular}

Means in the same column/row with different superscript differ significantly $(P<0.05)$ or highly significant $(\mathrm{P}<0.01)$

Canul-Solis et al. (2014) reported that administration of saponin from Yucca schidigera did not affect weight gain and feed efficiency of sheep fed Pennisetum purpureum grass. Similar results were reported by Aazami et al. (2013) that the addition of saponins 0,100 and $100 \mathrm{mg}$ / kg DM in sheep / goat diets did not have an effect on weight gain.

Although there were no significant differences statistically, however, the group of cows that received flower extract tended to have better ADG, FC and FE than the control group (Table 4). This is due to DMD, OMD, NDFD and feed ADFD in the second group was higher ( $P$ $<0.05)$ compared to the control cattle group (group I). It is suspected that flavonoid levels in Waru flower extract contributed to differences in data between cows in groups I and II. It was postulated that the effect of saponin varied with type of diet, nature of saponin and dose level, which may be the reason for the difference in the effects (Patra and Saxena, 2010).

\section{Conclusions}

H.tiliaceus flower extract supplementation of $200 \mathrm{ppm} / \mathrm{kg}$ dry matter in the diet of Bali cattle can increase the digestibility of dry matter (DMD), organic matter (OMD), neutral detergent fiber (NDFD), acid detergent fiber (ADFD).

\section{Acknowledgement}

This research was financially supported by the Indonesian Ministry of Research Technology and Higher Education.

\section{References}

Aazami, MH, AM Tahmasbi, MH Ghaffari, AA Naserian, R Valizadehand, AH Ghaffari. 2013.
Effects of Saponins on Rumen Fermentation, Nutrients Digestibility, Performance, and Plasma Metabolites in Sheep and Goat Kids. Annual Review \& Research in Biology 3(4): 596-607.

AOAC. 2012. Official method of analysis of AOAC International. $19^{\text {th }}$ ed. Assoc. of Off.Anal. Chem., Maryland, USA.

Balcells, J, A Aris, A Serrano, AR Seradj, J Crespo, and M Devant. 2012. Effects of an extract of plant flavonoids (Bioflavex) on rumen fermentation and performance in heifers fed highconcentrate diets. Journal of Animal Science, vol. 90, no. 13, pp.4975-4984. https://doi.org/10.2527/jas.20114955

Baraka, TAM and MA Abdl-Rahman. 2012. In vitro evaluation of sheep rumen fermentation pattern after adding different levels of eugenol-fumaric acid combinations. Veterinary World, 5, 110-117.

Belanche, A, G Fuente, CJ Newbold. 2014. Study of methanogen communities associated with different rumen protozoal populations. FEMS Microbiol Ecol 90: 663-677. DOI: 10.1111/15746941.12423

Barham, D and P Trinder. 1972. An improved color reagent for the determination of blood glucose by the oxidase system. Analyst 97: 142-145.

Bata, M and S Rahayu. 2016. Study of Hibiscus tiliaceus Leaf Extract Carrier as Additive in the Diets for Fattening of Local Cattle (in vitro). Pakistan Journal of Nutrition 15(11): 969-974. https://doi.org/10.3923/pjn.2016.969.974.

Bata, M and S Rahayu. 2017. Evaluation of Bioactive Substances in Hibiscus tiliaceus and Its Potential as a Ruminant Feed Additive. Current Bioactive Compounds 13:1157164. https://doi.org/10.2174 /1573407213666170109151904

Becker, PM, PG van Wikselaar, MCR Franssen, $\mathrm{RCH}$ de Vos, and RD Hall, J Beekwilder. 2014. Evidence for a hydrogen-sink mechanism of $(+)$ catechinmediated emission reduction of the ruminant greenhouse gas methane. Metabolomics, 10, 179-189. https://doi.org/10.1007/s11306-0130554-5

Bodas, R, N Prieto, R Garcia-Gonzalez, S Andres, FJ Giraldez, and S Lopez. 2012. Manipulation of rumen fermentation and methane production with plant secondary metabolites. Animal Feed 
Science and Technology. 176(1-4):78-93. https://doi.org/10.2478/aoas-2018-0037.

Biro Pusat Statistik. 2016. Nusa Tenggara Timur Dalam Angka. Biro Pusat Statistik, Kupang-Nusa Tenggara Timur.

Chaney, AL and EP Marbach. 1962. Modified reagents for determination of urea and ammonia. Clin Chem. 8:130.

Chen, XB and MJ Gomes. 1995. Estimation Of Microbial Protein Supply To Sheep And Cattle Based On Urinary Excretion Of Purine Derivatives: An Overview of The Technical Details. International Resources Unit, Rowett Research Institute, Bucksburn Aberdeen, UK.

Canul-Solis, AJR, AT Piñeiro-VázquezA, EG BriceñoPoot, et al. 2014. Effect of supplementation with saponins from Yucca schidigera on ruminal methane production by Pelibuey sheep fed Pennisetum purpureum grass. Anim. Production Sci. 54(10):1834-1839. DOI: 10.1071/AN14296

Cruz, OTB, MV Valero, F Zawadzki, DC Rivaroli, RM Prado, BS Lima, IN Prado. 2014. Effect of glycerine and essential oils (Anacardium occidentale and Ricinus communis) on animal performance, feed efficiency and carcass characteristics of crossbred bulls finished in a feedlot system. Italian J. of Anim. Sci. 13: 790-797

Faniyi, TO, MK Adewumi, ÊR Prates, AS Ayangbenro. 2016. Effect of herbs and spices (plant extracts) on rumen microbial activities: a review. PUBVET v.10, n.6, p.477-486. D.O.I.: https://doi.org/10.22256/pubvet.v10n6.477-486

Geraci, JI, AD Garciarena, GA Gagliostro, KA Beauchemin, D Colombatto. 2012. Plant extracts containing cinnamaldehyde, eugenol and capsicum oleoresin added to feedlot cattle diets: Ruminal environment, short term intake pattern and animal performance. Anim. Feed Sci. and Technol. 176: 123-130.

Goel, G, and HPS Makkar. 2012. Methane mitigation from ruminants using tannins and saponins. Trop. Anim. Health Prod. 44:729-739. DOI 10.1007/s11250-011-9966-2

Greening, C, R Geier, C Wang, LC Woods, SE Morales, MJ McDonald, R Rushton-Green, XC Morgan, S Koike, SC Leahy, and WJ Kelly. 2019. Diverse hydrogen production and consumption pathways influence methane production in ruminants. The ISME Journal https://doi.org/10.1038/s41396019-0464-2

Gunawan, A, R Sari, Y Parwoto and MJ Uddin. 2011. Non genetic factors effect on reproductive performance and preweaning mortality from artificially and naturally bred in Bali Cattle. J. Indonesian Trop. Anim.Agric. 36(2) :83-90. http://doi.org/10.14710/jitaa.36.2.83-90.
Guyader, J, M Eugène, M Doreau, DP Morgavi, C Gérard, C Loncke, C Martin. 2015. Tea saponin reduced methanogenesis in vitro but increased methane yield in lactating dairy cows. J. Anim. Sci. 93: 5367-5377.

Hasan, SA and AA Saeed. 2012. Effect of Feeding Different Levels of Dietary Protein with High or Low Rumen Degradable: Undegradable Dietary Nitrogen on Awassi Lambs Performance 3Selected Biochemical Parameters. KSU J. Nat. Sci. 15(3):36_45. http://dergipark.gov.tr/download/a rticle-file/212020.

Jayanegara, A, F Leiber, and M Kreuzer. 2012. Meta analysis of the relationship between dietary tannin level and methane formation in ruminants from in vivo and in vitro experiments. J. of Anim. Physiol. and Anim. Nutr. 96: 365-375.

Kim, E, CH Kim, KS Min and S Lee. 2012. Effects of plant extracts on microbial population, methane emission and ruminal fermentation characteristics in in vitro. Asian-Australasian Journal of Animal Sciences, 25, 806-811.

Kim, ET, LL Guan, SJ Lee, SM Lee, SM Lee, SS Lee, ID Lee, SK Lee and SS Lee. 2015. Effects of flavonoidrich plan extract on In Vitro ruminal methanogenesis, microbial population and fermentation characteristics. Asian Australas. J. Anim. Sci. 28:4: $530 \quad$ - 537. https://doi.org/10.5713/ajas.14.0692 .

Kumar, S, D Kumar, and O Prakash. 2008. Evaluation of antioxidant potential, phenolic and flavonoid contents of Hibiscus tiliaceus flowers. Electronic Journal of Environmental Agricultural and Food Chemistry, 7: 2863_2871.https://www.researchg ate.net/publication /266233970.

Kumar, M, A Kannan, R Bhar, A Gulati, A Gaurav and VK Sharma. 2017. Nutrient intake, digestibility and performance of Gaddi kids supplemented with tea seed or tea seed saponin extract. Asian-Australas J Anim Sci Vol. 30, No. 4:486-494. https://doi.org/10.5713/ajas.16.0451

Liu, Y, T Ma, D Chen, N Zhang, B Si, K Deng, Y Tu and Q Diao. 2019. Effects of Tea Saponin Supplementation on Nutrient Digestibility, Methanogenesis, and Ruminal Microbial Flora in Dorper Crossbred Ewe. Animals 9 (29): 1-11. DOI:10.3390/ani9010029

McDonald, P, RA Edwards, JFD Greenhalgh, CA Morgan, LA Sinclair, and RG Wilkinson. 2010. Animal Nutrition. $7^{\text {th }}$ Ed. Longman Scientific and Technical, New York.

Nasri, S, HB Salem, V Vasta et al. 2011. Effect of increasing levels of Quillaja saponariaon digestion, growth and meat quality of Barbarine lamb. Anim Feed Sci Technol 164:71-78. htpps://doi.org/10.1016/j.anifeedsci.2010.12.00 5. 
Ngadiyono, N. 2012. Growth and carcass characteristics of Sumba Ongole, Brahman cross and Australian commercial cross beef maintained intensively in various slaughter weights. [dissertation] Postgraduate Programme, Bogor Agriculture University.

Nozad, S, AG Ramin, G Moghadam, S Asri-Rezaei, A Babapour, and S Ramin. 2012. Relationship between blood urea, protein, creatinine, triglycerides and macromineral concentrations with the quality and quantity of milk in dairy Holstein cows. Veterinary Res. Forum. 12: 3 (1): 55 $-59$

Oskoueian, E, N Abdullah and A Oskoueian. 2013. Effects of Flavonoids on Rumen Fermentation Activity, Methane Production, and Microbial Population. Biomed.Res. Int.: 349129. http://dx.doi.org/10.1155/2013/ 349129

Patra, AK and J Saxena. 2010. A new perspective on the use of plant secondary metabolites to inhibit methanogensis in the rumen. Phytochemistry 71:1198_222. https://doi.org/10.1016/j.phytoch em.2010.05.010

Smith, FE and TA Murphy. 1993. Analysis of rumen ammonia and blood urea nitrogen. https://animalscience.unl.edu/Research/RumNut /RumNutLab/96-bloodureanitrogen .pdf

Van Soest, PJ, JB Robertson, and BA Lewis. 1991. Methods fordietary fiber, neutral detergent fiber and non-starch polysaccharides (NSP) in relation to animal nutrition. Journal of Dairy Science, v. 74, p.3583-3597, 1991. https://doi.org/10.3168/ jds.S0022-0302(91)78551-2

Wang, CJ, SP Wang, H hou. 2009. Influences of flavomycin, ropadiar, and saponin on nutrient digestibility, rumen fermentation, and methane emission from sheep. Anim. Feed Sci. and Technol. 148 (2-4): 157-166.

Wang, JK, JA Ye, JX Liu. 2012. Effects of tea saponins on rumen microbiota, rumen fermentation, methane production and growth performance a review. Tropical Anim Health Prod 44:697-706. https://doi.org/ 10.1007/s11250-011-9960-8

Yildiz, G, A Tekeli, W Drochner, and H Steingass. 2015. Determination of the effects of some plant extracts on rumen fermentation and protozoal counts by hohenheim in vitro gas production Technique. Internat. J. of Anim. and Veterinary Advances 7: 18-26.

Wiswata, IGNA, IK Widnyana, and BP Udiyana. 2016. Study on Cattle Fodder Avaibility to Support The Development of Balinese Cattle in Bali. Proceeding $2^{\text {nd }}$ International Conference on Sustainability Development Global Sustainable Development. 28 Feb-01 March 2015, BaliIndonesia. https://unmas.ac.id/wpcontent/uploa ds/2016/10/2nd-ICSD-Proceedings-fix.pdf 